\title{
Perusahaan Manufaktur di Bursa Efek Indonesia: Tax Avoidance Dijelaskan oleh Variabel Proporsi Dewan Komisaris, Ukuran Perusahaan, Profitabilitas dan Leverage
}

\author{
Purwaningsih \\ p.ningsih12@gmail.com \\ Accounting Study Program, Faculty of Business \\ President University, Cikarang, Indonesia \\ Andrianantenaina Hajanirina \\ hajanirina@president.ac.id \\ Accounting Study Program, Faculty of Business \\ President University, Cikarang, Indonesia

\section{Ika Pratiwi Simbolon} \\ ika.pratiwi@president.ac.id \\ Accounting Study Program, Faculty of Business \\ President University, Cikarang, Indonesia
}

\begin{abstract}
Taxpayers such as companies can take advantage of the shortcomings of tax law (loophole) by doing tax avoidance. Aiming to further analyse tax avoidance; the proportion of independent commissioners, company size, profitability (ROA) and leverage are selected. Using manufacturing companie as samples, they are listed on the Indonesia Stock Exchange (IDX) from 2015 to 2017. This study uses purposive sampling, those samples are composed of 63 companies. In fact, panel data are used for that. The results of the study show that company size and leverage affect tax avoidance. The limitation in this study is that the number of company used for the three year of observation is 63 companies only and the variables used are only the independent commissioners, company size, profitability (ROA) and leverage.
\end{abstract}

Keywords: tax avoidance; proportion of independent commissioner, company size; leverage

\begin{abstract}
Abstrak
Wajib pajak seperti perusahaan dapat memanfaatkan kekurangan dari undang-undang perpajakan (loophole) dengan melakukan tax avoidance. Tujuan penelitian ini adalah untuk mengetahui lebih lanjut bagaimana tax avoidance dapat dijelaskan oleh variable proporsi dewan komisaris independen, ukuran perusahaan, profitabilitas (ROA) dan leverage. Untuk itu, perusahaan manufaktur yang terdaftar di Bursa Efek Indonesia (BEI) periode tahun 2015 - 2017 menjadi sampel. Terdapat 63 perusahaan yang diambil melalui purposive sampling. Metode analisis penelitian ini menggunakan anlsisis regresi data panel. Hasil penelitian menujukkan bawa tax avoidance dapat dijelaskan oleh ukuran perusahaan dan leverage. Keterbatasan dalam penelitian ini adalah jumlah sampel perusahaan yang digunakan hanya dalam periode waktu tiga tahun sebanyak 63 perusahaan dan variabel yang digunakan hanya proporsi dewan komisaris independen, ukuran perusahaan, profitabilitas serta leverage.
\end{abstract}

Kata Kunci: tax avoidance; proporsi dewan komisaris; ukuran perusahaan; profitabilitas (ROA); leverage 


\section{PENDAHULUAN}

Sehubungan denga usaha pembiayaan dan pembangunan Negara, pembayaran pajak adalah bentuk dari kewajiban masyarakat sebagai wajib pajak. Menurut Maharani dan Suardana (2014) pajak merupakan beban sebab mengurangi pendapatan ataupun penghasilan masyarakat, apalagi masyarakat tidak menerima timbal balik langsung setelah melakukan pembayaran pajak. Tax avoindance (penghindaran terhadap pembayaran pajak) merupakan cara untuk mengurangi maupun menghindarkan pembayaran pajak secara legal. Tax avoidance menjadi persoalan yang unik dan rumit dikarenakan hal ini diperbolehkan, tetapi tidak diinginkan oleh semua negara. Tindakan penghindaran pada pajak dibedakan menjadi dua yaitu penghindaran terhadap pajak yang dapat diterima untuk dapat dilakukan dan penghindaran pajak yang tidak bisa diterima ataupun dilakukan. Tax avoidance menurut Darmawan dan Sukartha (2014) adalah upaya dalam mengurangi besaran pembayaran terhadap pajak secara sah dan resmi, apabila tidak legal, disebut tax evasion.

Berdasarkan teori keagenan adanya kepentingan antara fiskus/administrasi pajak dengan perusahaan yang tidak sama bisa menyebabkan tindakan tidak patuh pada pajak yang dilakukan para wajib pajak ataupun pihak manajemen pada perusahaan sehingga menimbulkan tindakan untuk melakukan tax avoidance. Sementara konsekuensi dari pembayaran pajak juga adalah faktor pendorong perusahaan pada saat mengambil sejumlah keputusan serta tindakan manajerial agar dapat mengurangi kewajiban pembayaran pajak dari perusahaan dianggap hal penting dari kegiatan perusahaan (Desai \& Dharmapala, 2005). Pada kenyataannya perusahaan yang merupakan wajib pajak badan pada kenyataannya dalam pengaturan pada struktur tata kelola perusahaan mempengaruhi cara sebuah perusahaan dalam memenuhi kewajiban perpajakannya, tetapi di sisi lain perencanaan pajak tergantung pada dinamika tata kelola perusahaan dalam suatu perusahaan (Friese et al., 2006).

Dengan adanya komite independen di perusahaan maka komite dapat semakin memberikan pengawasan atas laporan keuangan yang akan menjadi lebih ketat dan obyektif, sehingga meminimalisir perilaku curang oleh manajer untuk memanipulasi laba. Hal ini dapat mengatasi manajemen laba (Dananjaya \& Ardiana, 2016). Keberadaan komisaris independen diatur pada Keputusan Direksi PT. Bursa Efek Indonesia (BEI) No. Kep-339/BEJ/07-20010 dimana menyampaikan jika setiap perusahaan publik harus dibentuk komisaris independen dimana anggotanya setidaknya paling kecil 30\% dari jumlah semua jumlah anggota dewan komisaris yang ada dalam perusahaan. Dewan komisaris yang terdiri atas dewan komisaris yang independen dengan jumlah yang lebih besar mempunyai pengawasan yang cukup besar dan kuat pada keputusan yang diambil manager.

Penelitian sebelumnya oleh Maharani dan Suardana (2014) menghasilkan bahwa proporsi dewan komisaris independen berpengaruh secara negatif terhadap tax avoidance. Dewi dan Jati (2014) serta Tandean dan Winnie (2016) juga menyebutkan dalam penelitiannya bahwa jumlah proporsi pada dewan komisaris independen tidak mempengaruhi pada tingkat tax avoidance pada perusahaan dan hal ini memberikan arti bahwa adanya dewan komisaris independen pada suatu perusahaan menjadi tidak efektif dalam usaha pencegahan tax avoidance. Akan tetapi pada penelitian lainnya oleh Yuliani dan Suyanto (2019) memperlihatkan bahwa jumlah proporsi dewan komisaris independen mempengaruhi dengan positif dan signifikan terhadap aggressive_tax avoidance pada perusahaan yang bergerak dalam bidang manufaktur. Maka semakin banyak jumlah komisaris independen di satu perusahaan akan berakibat semakin lebih besar penghindaran pajak yang dilakukan, sehingga jumlah uang kas yang dilakukan untuk melakukan pembayaran pajak (CETR) menjadi semakin lebih kecil. 
Faktor lainnya yang juga dapat mengubah tingkat tax avoidance yaitu ukuran perusahaan (size). Pada penelitian yang telah dilakukan sebelumnya terkait-ukuran perusahaan ini sudah banyak yang dilakukan, yaitu Dewi dan Jati (2014) yang menunjukkan dalam penelitiannya yang menyebutkan ukuran perusahaan tidak mempengaruhi besar kecilnya tax avoidance. Tidak adanya pengaruh pada variabel ukuran perusahaan ini dikarenakan melakukan pembayaran pada pajak adalah suatu kewajiban semua persorangan maupun perusahaan. Pada perusahaan baik berskala besar maupun perusahaan berskala kecil, akan selalu dikejar oleh fiskus/administrasi pajak jikalau melanggar ketentuan peraturan pada perpajakan yang berlaku. Sedangkan menurut Darmawan dan Sukartha (2014), Swingly dan Sukartha (2015), Dharma dan Ardiana (2016), Diantari dan Ulupui (2016) juga menyampaikan bahwa ukuran pada perusahaan mempengaruhi pada penghindaran pajak perusahaan, makin besar suatu perusahaan dimana sumber daya yang akan dimiliki oleh perusahaan tersebut makin besar pula yang dapat digunakan untuk mengelola beban pada pembayaran pajak perusahaan.

Profitabilitas pada satu perusahaan dapat memperlihatkan mampu atau tidaknya satu perusahaan untuk dapat mendapatkan laba pada periode waktu tertentu serta pada tingkatan penjualan, jumlah asset, dan pada saham tertentu. Salah satu rasio probabilitas yakni return on asset (ROA). Profitabilitas tersebut dapat menggambarkan posisi keuangan di perusahaan, jadi semakin besar nilainya yang didapatkan maka dianggap performa keuangan di perusahaan itu bisa dikatakan dalam kondisi baik (Kurniasih \& Sari, 2013). Semakin tinggi nilai profitabilitas yang dicapai oleh suatu perusahaan dapat dianggap performa keuangan pada perusahaan itu dalam performa yang baik.

Menurut Maharani dan Suardana (2014) serta Arianandini dan Ramantha (2018) dalam penelitiannya menyampaikan tax avoidance dipengaruhi secara negatif oleh profitabilitas dan ini memberikan arti semakin besar profitabilitasnya maka perusahaan akan semakin menekan tindakan tax avoidance. Sedangkan menurut Darmawan dan Sukartha (2014) tax avoidance dipengaruhi secara positif oleh profitabilitas disebabkan pada perusahaan yang bisa mengelola asetnya dengan cukup baik maka dari itu bisa mendapatkan keuntungan dari kewajiban pembayaran pajak serta kelonggaran dalam pembayaran pajak yang lain maka dari itu perusahaan akan terlihat dalam melakukan penghindaran pembayaran pajak.

Ada komponen lainnya yang bisa mempengaruhi tax avoidance yakni leverage di perusahaan. Terdapat indikasi pada perusahaan yang mengambil kebijakan pendanaan yang merupakan tindakan untuk melakukan penghindaran pada pembayaran pajak, contohnya yaitu kebijakan pada leverage yakni tingkatan hutang pada perusahaan yang dipakai perusahaan untuk membayar biaya operasi pada perusahaannya (Dharma \& Ardiana, 2016). Apabila pembiayaan dari $100 \%$ hutang dihindari, perlunya mempertimbangkan biaya hutang atau kesulitan keuangan yang biasa dikenal dengan nama cost of bakcruptcy sehingga perusahaan yang tidak akan mendapatkan keuntungan maksimal dari pendanaan pada utang $100 \%$ (Arianandini \& Ramantha, 2018).

Beban bunga akan timbul jika perusahaan melakukan penambahan jumlah hutang dan hal ini menjadi mengurangi beban dari laba bersih di perusahaan yang pada akhirnya bisa menjadi pengurang pajak (Darmawan \& Sukartha, 2014). Hal ini sesuai dengan penelitian yang dilakukan oleh Dewinta dan Setiawan (2016) dimana tax avoidance dipengaruhi secara positif oleh leverage.

\section{TINJAUAN PUSTAKA}

\section{Teori Keagenan (Agency theory)}

Suatu hubungan agensi bisa terjadi bila seseorang atau lebih (principal) mempekerjakan seseorang atau pihak lain (yaitu agent) agar dapat memberikan sesuatu jasa tertentu lalu memberikan delagasi kewenangan dalam melakukan pengambilan suatu keputusan (Jensen dan Meckling, 1976). Principal adalah investor atau pemilik saham, disisi lain agent adalah 
pihak manajemen yang bertugas melakukan pengelolaan suatu perusahaan atau disebut juga manajer. Pemisahan wewenang, kewajiban serta fungsi diantara pemilik saham ataupun investor juga hubungan pengendalian oleh manajemen adalah inti hubungan keagenan.

Masalah pada keagenan dapat dikarenakan adanya ketidaksesuaian kepentingan antara pemilik saham (principal) dengan pihak dari manajemen di suatu perusahaan (agent) (Dananjaya \& Ardiana, 2016). Ketika ada kepentingan agen yang berbeda dan principal memiliki perilaku penghindaran pajak yang agresif, maka hal ini memungkinkan terjadinya masalah keagenan (Tandean \& Winnie, 2016). Hal tersebut dapat terjadi sebab melalui laba yang tinggi manajemen ingin meningkatkan kompensasi. Namun pemilik saham menginginkan reduksi biaya pajak dengan laba yang lebih rendah.

Sesuai dengan pendapat Jensen dan Meckling (1976); agency cost terdiri dari tiga cost tentang monitoring, bonding dan residual loss. Cost yang pertama adalah pembiayaan dibayar principal guna melakukan pengukuran, pengamatan dan pengawasan perilaku serta sikap agent supaya tidak terjadi penyimpangan. Monitoring cost timbul dikarenakan terdapat ketidaksesuaian data antara principal dengan agent. Pada kondisi tertentu, kemungkinan agent membelanjakan sumber daya perusahaan (bonding cost) sebagai jaminan agar agent tidak mungkin melakukan tindakan yang bisa menimbulan kerugian terhadap principal, ataupun agar principal yakin akan memberi semacam timbal balik bila tindakan tersebut benar-benar dilakukan. Namun, ketidaksamaan antara keputusan agent dengan keputusan yang bisa memaksimalkan kesejahteraan agent masih bisa terjadi. Nilai pada uang yang berbanding lurus dengan kesejahteraan yang kurang yang dialami principal disebut residual loss.

Menurut Armstrong et al. (2015) di bawah pandangan alternative agency theory, penghindaran pajak merupakan investasi alternatif beresiko. Sebagai keputusan investasi; masalah keagenan yang tak selesai bisa mengakibatkan berbedanya tingkatanpada penghindaran pajak yang mana dikehendaki para manajer dan pemilik saham. Peluang dalam rangka pengalihan manajerial selalu dihasilkan oleh pengendalian pajak. Penghindaran pajak dapat diatasi dengan insentif kompesasi bagi manajer. Menurut Kurniasih dan Sari (2013) teori keagenan memberikan pernyataan bahwa adanya asimetris informasi dari manajer (agent) terhadap pemilik saham (principal) sebab manajer lebih paham betul informasi dalam internal perusahaan serta prospek di perusahaan di waktu yang akan datang jika dibanding degan pemilik saham dan stakeholder yang lainnya.

\section{Tax avoidance}

Berdasarkan pada Undang-Undang Republik Indonesia No.16, 2009 tentang Ketentuan Umum dan Tata Cara Perpajakan di Pasal 11 ayat 1, pengertian dari pajak yakni kontribusi yang harus dilakukan untuk negara bersifat terutang oleh orang pribadi ataupun badan yang bersifat memaksa karena sesuai dengan undang-undang, dengan tidak mendapatkan imbalan secara langsung dan dipergunakan untuk keperluan suatu negara serta sebesar-besarnya bagi kemakmuran rakyat.

Tax avoidance merupakan cara untuk mencegah wajib pajak membayar utangnya secara hukum, yaitu mengurangi kewajiban kena pajak tanpa melanggar peraturan perpajakan, atau melakukan kewajiban dengan mencari kelemahan dalam peraturan perpajakan (Hutagaol, 2007). Menghindari pajak perusahaan bertujuan untuk mengurangi kewajiban perpajakan perusahaan secara signifikan (Annuar et al., 2014).

Tax avoidance juga mengurangi beban perusahaan yang sering membayar pajak karena masih dalam kerangka peraturan perpajakan yang berlaku (Darmawan \& Sukartha, 2014). Menurut Eksandy (2017) tax avoidance bisa menjadi skema transaksi yang dilakukan dalam upaya meminimalisir beban pembayaran pajak yakni dengan memanfaatkan kelemahan (loophole) pada ketentuan perpajakan. 


\section{Proporsi Dewan Komisaris Independen}

Sebagai Dewan Komisaris Independen yang bukan berasal dari dalam perusahaan (Putra \& Nuzula, 2017), level tertinggi setelah pemegang saham dipegang oleh komisaris. Dewan Komisaris berperan sentral pada tata kelola di perusahaan sebab perusahaan bertanggungjawab secara legal dan hukum untuk memfokuskan pada kepentingan perusahaan serta dewan komisaris ketika tujuan telah ditetapkan. Secara kolektif, dewan komisaris bertanggung jawab untuk meninjau dan mengawasi kinerja para manajer atau manajemen dan memastikan jalannya perusahaan dengan baik serta melindungi kepentingan pemegang saham (Tandean \& Winnie, 2016).

Anggota dewan terdiri dari dewan komisaris yang independen berjumlah yang besar mempunyai pengawasan yang kuat pada keputusan manajerial (Dananjaya \& Ardiana, 2016). Persentase komposisi jumlah dewan komisaris independen yang semakin besar di dalam struktur dewan komisaris perusahaan menyebabkan semakin tinggi pula penghindaran pajakmyang ditimbulkan (Eksandy, 2017). Menurut Yuliani dan Suyanto (2019) semakin banyaknya jumlah dari komisaris independen yang tidak profesional maka kinerja dihasilkan komisaris independen semakin buruk. Sehingga keberadaan komisaris di suatu perusahaan hanya dianggap sebagai formalitas. Dengan demikian, kinerja yang dihasilkan oleh dewan komisaris independen tidak dapat membantu perusahaan dalam meminimalkan penghindaran pajak.

\section{Ukuran perusahaan (Size)}

Ukuran perusahaann atau Size adalah tingkat ukuran besar maupun kecilnya pada suatu perusahaan (Dharma \& Ardiana, 2016). Ukuran perusahaan terdiri dari dua kriteria yakni perusahaan yang besar dan yang kecil. Perusahaan dengan total aset besar mempresentasikan pencapaian tahap jatuh tempo. Perusahaan tersebut dianggap memiliki arus kas yang positif dan mempunyai prospek bagus pada periode cukup lama. Ukuran perusahaan yang semakin besar, memiliki kemungkinan yang besar dalam tindakan penghindaran pajak (Tandean \& Winnie, 2016). Jumlah produktifitas perusahaan dipengaruhi oleh besar kecilnya aset. Jadi ukuran perusahaan juga mempengaruhi laba yang dihasilkan. Menurut Dharma dan Ardiana (2016) perusahaan beraset besar akan memengaruhi pembayaran pajak perusahaan.

\section{Profitabilitas (ROA)}

Profitabilitas adalah satu cara untuk menjadi pengukur performa suatu perusahaan. Profitabilitas perusahaan menampilkan kemampuan pada perusahaan untuk menghasilkan dan mendapatkan keuntungan pada suatu periode di tingkat penjualan, aset serta modal pada saham yang tertentu (Dewinta \& Setiawan, 2016). Menurut Arianandini dan Ramantha (2018) profitabilitas menggambarkan kemampuan perusahaan dalam memanfaatkan asetnya secara efisien pada mendapatkan laba perusahaan dari pengelolaan pada aktiva yang dikenal dengan ROA.

ROA yang positif akan menunjukkan bahwa dari total aktiva yang dipergunakan dalam operasi perusahaan dapat menghasilkan nilai laba untuk perusahaan. ROA dinyatakan dalam tingkatan prosentase, dimana semakin tinggi nilai ROA pada perusahaan maka akan semakin baik kinerja pada perusahaan tersebut. Laba merupakan dasar dari pengenaan pajak. Semakin tinggi laba satu perusahaan sehingga beban pajak yang dibayarkan juga semakin tinggi. Perusahaan mendapatkan jumlah laba dianggap tidak melakukan tax avoidance karena dapat mengelola pendapatan dan pembayaran pajaknya (Maharani \& Suardana, 2014). 


\section{Leverage}

Leverage mempresentasikan resiko perusahaan, pengukurannya dilakukan dengan cara membandingkan jumlah dari total hutang dengan total asset pada perusahaan. Jumlah hutang yang ada dalam neraca baik hutang jangka pendek maupun jangka panjanglah yang akan dipakai dalam penghitungan rasio hutang (Dharma \& Ardiana, 2016).

Hutang yang dimiliki dengan nilai yang semakin besar jumlahnya, mengakibatkan semakin kecil laba yang dikenakan pajakn (Yuliani dan Suyanto, 2019). Hal ini diakibatkan oleh insentif pembayaran pajak dari bunga utang yang semakin besar jumlahnya. Biaya dari bunga dengan nilai yang semakin tinggi akan mempengaruhi terhadap berkurangnya beban pajak perusahaan, maka dari itu semakin tinggi rasio dari leverage, akan berimplikasi bahwa tax avoindance oleh perusahaan juga menurun. Untuk itu, debt to equity ratio (DER) digunakan untuk mengukur seberapa besar kewajiban dari iperusahaan dalam rangka membiayai operasional dengan total utang.

\section{Kerangka Pemikiran dan Hipotesis}

\section{Pengaruh Proporsi Dewan Komisaris terhadap Tax avoidance}

Kewenangan dalam pengelolaan perusahaan diberikan oleh pemilik perusahaan kepada pengelolanya yaitu manajer perusahaam untuk melakukan pengurusan untuk menjalankan perusahaan seperti melakukan pengelolaan pendanaan dan pengambilan keputusan di dalam suatu perusahaan dengan atas nama pemilik perusahaan. Manajer atau pengelola perusahaan tidak bersikap dan bertindak dalam perusahaan atas kemauan dari pemilik perusahaan, oleh karena adanya ketidaksamaan pada kepentingan (conflict of interest) (Putra \& Nuzula, 2017). Teori keagenan menyebutkan jika semakin banyak jumlah suatu dewan komisaris independen, maka hal tersebut akan menjadi semakin baik pula dalam melakukan pengawasan dan pengendalian pada tindakan para direktur eksekutif dan tindakan direksi, yang berhubungan dengan perilaku oportunistik yang cenderung mereka miliki (Jensen \& Meckling, 1976).

Beberapa penelitian sebelumya menemukan berbagai hasil pengaruh dari keberadaan proporsi dewan komisaris independen pada perusahaan terhadap tax avoidance. Annisa dan Kurniasih (2016), Maharani dan Suardana (2014), Dewi dan Jati (2014), dan juga Tandean dan Winnie (2016) menenemukan bahwa tax avoidance tidak dipengaruhi oleh adanya jumlah proporsi dewan komisaris independen. Sedangkan menurut Eksandy (2017), Yuliani dan Suyanto (2019) komposisi dari jumlah dewan komisaris independen berpegaruh secara positif pada tax avoidance, dimana saat jumlah komisaris independen makin banyak, maka penghindaran pajak yang dilakukan semakin menjadi besar pula. Menurut Diantari dan Ulupui (2016) komposisi dari dewan komisaris independen mempengaruhi secara negatif pada tax avoidance, hal ini memberikan arti bahwa keberadaan dari komisaris independen berpengaruh efektif dalam melakukan pencegahan tax avoidance.

Dengan jumlah komisaris independen banyak yang tidak profesional pada suatu perusahaan maka kinerja yang dihasilkan oleh komisaris independen semakin buruk, sehingga keberadaan komisaris di suatu perusahaan hanya dianggap sebagai formalitas. Dengan demikian, kinerja yang dihasilkan oleh dewan komisaris independen tidak dapat membantu perusahaan dalam meminimalkan terjadinya penghindaran pajak. Berdasarkan penjelasan di atas bisa disimpulkan hipotesis pertama yaitu:

\section{$H_{1}$ : Proporsi komisaris independen berpengaruh negatif terhadap tax avoidance.}

\section{Pengaruh Ukuran Perusahaan terhadap Tax avoidance}

Dengan menggunakan jumlah aset, apabila, jumlah tersebut semakin tinggi, hal ini, menunjukkan besarnya perusahaan yang memiliki transaksi lebih kompleks (Dewi \& Jati, 
2014). Berdasarkan teori agensi, perusahaan dapat menggunakan sumber dayanya untuk memaksimalkan nilai kompensasi dari kinerja para agen, yakni dengan melakukan penekanan terhadap beban pajak pada perusahaan agar performa di dalam perusahaan maksimal (Dewinta \& Setiawan, 2016). Tekanan ini mengakibatkan perusahaan cenderung untuk melakukan penghindaran pada pembayaran pajak.

Penelitian-penelitian sebelumnya yang telah dilaksanakan oleh Darmawan dan Sukartha (2014), Swingly dan Sukartha (2015), Diantari dan Ulupui.(2016) serta Dewinta dan Setiawan (2016) menunjukkan penghindaran pada pajak dipengaruhi secara positif oleh ukuran perusahaan, hal ini memberikan makna bahwa apabila ukuran perusahaan yang semakin besar, maka aktivitas dari tax avoidance juga semakin tinggi pada perusahaan dimana hal dikarenakan perusahaan yang memili aset dalam jumlah yang relatifnbesar dimungkinkan lebih bisa, mampu serta stabil dalam rangka menghasilkan keuntungan ataupun laba. Dewi dan Jati (2014) mengemukakan bahwa penghindaran pajak tidak berkaitan dengan ukuran perusahaan. Namun menurut Dharma dan Ardiana (2016) ukuran perusahaan mempengaruhi secara negative pada tax avoidance. Berdasarkan uraian yang disampaikan tersebut maka dapat disimpulkan hipotesis ke dua yaitu:

\section{$\mathrm{H}_{2}$ : Ukuran perusahaan berpengaruh negatif terhadap tax avoidance.}

\section{Pengaruh profitabilitas terhadap Taxa avoidance}

ROA adalah salah satu dari beberapa cara yang dapat menunjukkan tingkatan profitabilitas pada perusahaan. Cara pendekatanmpada ROA menampilkan jika besaran labayang didapatkan perusahaan dalam memakai jumlah aset perusahaan yang telah dimilikinya. Dalam menghitung suatu kemampuan satu perusahaan dalam menghasilkan laba diluar pendanaan bisa melalui ROA (Darmawan \& Sukartha, 2014). Return of Asset (ROA) adalah satu dari beberapa rasio guna melakukan pengukuran keutungan bersih atau laba yang didapatkan dari berapa besar penggunakan asset oleh perusahaan (Kurniasih \& Sari, 2013).

Teori keagenan menyebutkan bahwa hal yang bisa memicu agent dalam melakukan peningkatan laba di perusahaan. Saat laba yang didapatkan meningkat, maka nilai dari pajak penghasilan yang harus dibayarkan juga akan naik sesuai dengan kenaikan laba pada perusahaan (Arianandini \& Ramantha, 2018). Praktik tax avoidance dapat didorong karena jumlah laba yang diterima perusahaan cukup besar dan stabil sebabbeban pajak dengan nilai yang besar disebabkan oleh laba yang besar (Dewinta \& Setiawan, 2016).

Menurut Darmawan dan Sukartha (2014) tax avoidance dipengaruhi oleh ROA pada peruasahaan. Menurut Dewi dan Wirajaya (2013) dan Dewinta dan Setiawan (2015) tax avoidance dipengaruhi secara positif oleh ROA pada peruasahaan. Namun menurut penelitian Arianandini dan Ramantha (2018) hubungannya negatif.

\section{$H_{3}:$ ROA berpengaruh negatif terhadap tax avoidance.}

\section{Pengaruh Leverage terhadap Tax avoidance}

Salah satu yang menunjukkan penghindaran pada pembayaran pajak yang berhubungan dengan tarif pajak efektif yakni keputusan pemilihan kebijakan pendanaan perusahaan. Keputusan pendanaan ini membuat perusahaan memutuskan untuk lebih menggunakan pendanaan secara internal maupun eksternal. Perusahaan yang mana memilih untuk lebih memanfaatkan pendanaan melalui ekternal contohnya dengan menggunakan utang yang menimbulkan adanya beban pada bunga yang bisa digunakan sebagai pengurangan laba yang dikenakan pajak (Dewinta \& Setiawan, 2016).

Menurut Dharma dan Ardiana (2016), Yuliani dan Suyanto (2019), Swingly dan Sukartha (2015) dan Arianandini dan Ramantha (2018) leverage secara signifikan dan negatif 
mempengaruhi tax avoidance. Serta menurut Dewinta dan Setiawan (2016) terdapat hubungan postifi antara leverage dan tax avoidance. Berdasarkan uraian diatas, maka hipotesis ke empat yaitu:

$H_{4}$ : Leverage berpengaruh positif terhadap tax avoidance.

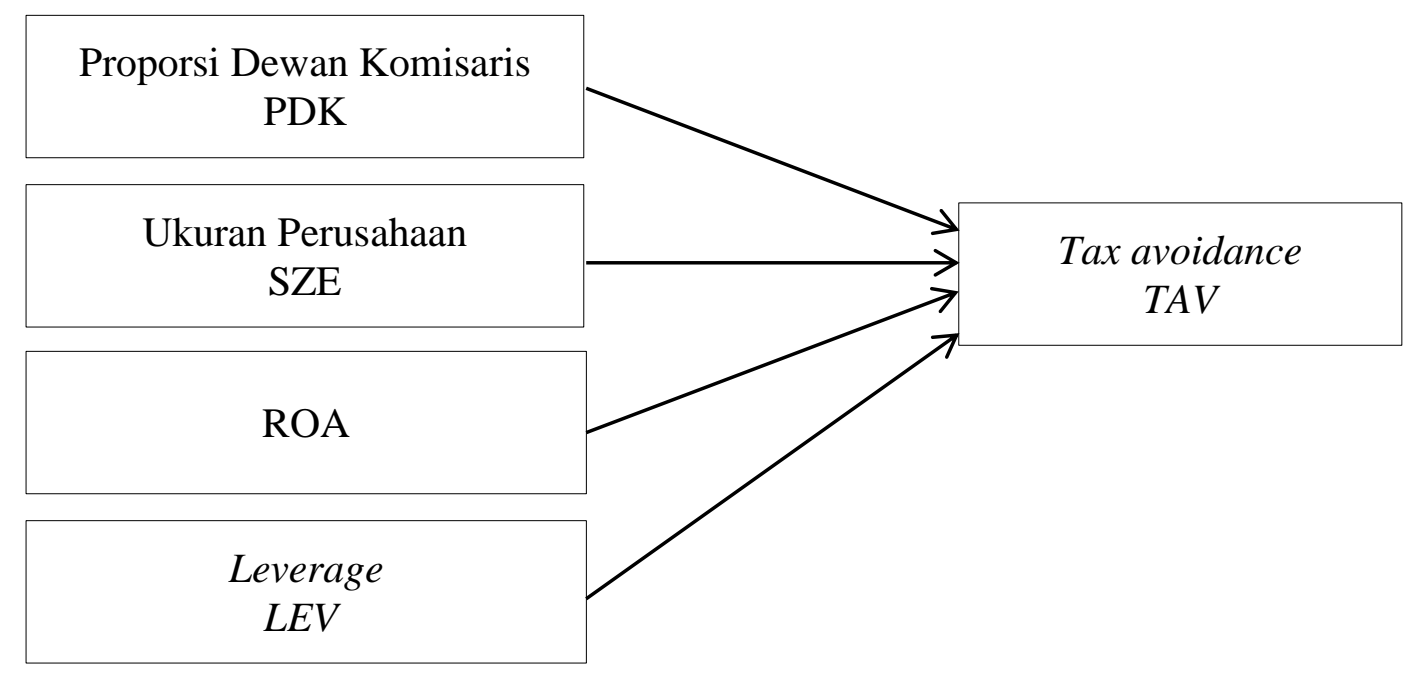

Gambar 1. Kerangka Penelitian

\section{METOD, HASIL DAN ANALISIS}

Data pada penelitian yang dilakukan ini yakni data sekunder, dimana data tersebut didapatkan melalui media perantara dengan kata lain data tak langsung (Sugiyono, 2013). Data diambil dari hasil laporan tahunan (annual report) serta laporan kinerja dari perusahaan manufaktur di BEI (2015 - 2017) melalui situs resmi www.idx.co.id (diakses pada tangal 17 April 2019). Serta data yang digunakan merupakan data panel dan diuji dengan menggunakan Eviews 8.0.

Dalam penelitian ini populasinya yakni seluruh perusahan dalam bidang industri manufaktur yang ada didaftar di BEI (2015 - 2017). Populasi penelitian ini terdiri dari 148 perusahaan. Sejumlah perusahaan tersebut akan diseleksi kembali dengan teknik purposive sampling, yaitu cara menentukan sample penelitian dengan menggunkanan beberapa pertimbanagan (Sugiyono, 2013). Alasan memakai perusahaan dalam bidang manufaktur sebagai sampel serta perusahaan tersebut ada dalam daftari Bursa Efek Indonesia yang dipilih dikarenakan pada perusahaan manufaktur memiliki jumlah aset tetap dalam jumlah yang besar jika dibandingkan dengan perusahaan dibidang industri yang lain, serta perusahaan manufaktur memberikan kontribusi yang cukup besar jika dibandingkan dengan perusahaan bidang industri lain di penerimaan pajak untuk negara.

Metode purposive sampling dipergunakan pada penelitian ini untuk menentukan sampel, yakni metode pemilihan sampel dengan pertimbangan beberapa hal tertentu, sehingga perusahaan yang tidak memenuhi ketentuan maupun kriteria yang ditetapkan akan dikeluarkan dari sampel. Kriteria pada penelitian yang dilakukan yaitu:

1. Perusahaan industry manufaktur yang ada dalam daftar perusahaan di Bursa Efek Indonesia (BEI) periode tahun 2015-2017. 
2. Laporan keuangan pada perusahaan / annual report menggunakan mata uang rupiah dalam pelaporan dengan periode akhir Desember 2017, hal ini dilakukan agar memiliki kriteria pengukuran dengan nilai mata uang yang tidak berbeda.

3. Perusahaan yang tidak mengalami kerugian atau dengan nilai laba positif atau tidak mengalami rugi pada periode $2015-2017$.

4. Perusahaan yang memiliki tax income positif periode 2015-2017.

5. Perusahaan tersebut mempunyai data lengkap sesuai dengan variabel yang digunakan.

Terdapat 63 perusahaan yang memenuhi syarat untuk dijadikan sampel dalam penelitian ini. Daftar perusahaan bidang manufaktur yang memenuhi syarat ketentuan sampel yaitu berikut:

Tabel 1a: Daftar Perusahaan Yang Memenuhi Kriteria Sampel

\begin{tabular}{|c|l|c|}
\hline No & \multicolumn{1}{|c|}{ Nama Perusahaan } & Kode Perusahaan \\
\hline 1 & Akasha Wira International Tbk & ADES \\
\hline 2 & Argha Karya Prima Industry Tbk & AKPI \\
\hline 3 & Alkindo Naratama Tbk & ALDO \\
\hline 4 & Asahimas Flat Glass Tbk & AMFG \\
\hline 5 & Arwana Citra Mulia Tbk & ARNA \\
\hline 6 & Astra International Tbk & ASII \\
\hline 7 & Astra Auto Part Tbk & AUTO \\
\hline 8 & Sepatu Bata Tbk & BATA \\
\hline 9 & Garuda Metalindo Tbk & BOLT \\
\hline 10 & Budi Starchand Sweetener Tbk & BUDI \\
\hline 11 & Cahaya Kalbar Tbk & CEKA \\
\hline 12 & Chitose Internasional Tbk & CINT \\
\hline 13 & Charoen Pokphand IndonesiaTbk & CPIN \\
\hline 14 & Delta Djakarta Tbk & DLTA \\
\hline 15 & Duta Pertiwi Nusantara & DPNS \\
\hline 16 & Darya Varia Laboratoria Tbk & DVLA \\
\hline 17 & Ekadharma International Tbk) & EKAD \\
\hline 18 & Gudang Garam Tbk & GGRM \\
\hline 19 & Indofood CBP Sukses MakmurTbk & ICBP \\
\hline 20 & Champion Pasific IndonesiaTbk & IGAR \\
\hline 21 & Impack Pratama IndustriTbk & IMPC \\
\hline 22 & Indofarma Tbk & INAI \\
\hline 23 & Intan Wijaya International Tbk & INCI \\
\hline 24 & Indofood Sukses Makmur Tbk & INDF \\
\hline 25 & Indospring Tbk & INDS \\
\hline 26 & Indocement Tunggal Prakasa Tbk & JPFA \\
\hline 27 & Steel Pipe Industry of Indonesia Tbk & KAEF \\
\hline 28 & Jembo Cable Company Tbk & \\
\hline 29 & Japfa Comfeed Indonesia Tbk & ISSP \\
\hline 30 & Kimia Farma Tbk & Sumbe: Data sekunder yang \\
\hline & & \\
\hline
\end{tabular}

Sumber: Data sekunder yang diolah 
Tabel 1b: Daftar Perusahaan Yang Memenuhi Kriteria Sampel

\begin{tabular}{|c|l|c|}
\hline 31 & KMI Wire and Cable Tbk & KBLI \\
\hline 32 & Kedaung Setia Industrial Tbk & KDSI \\
\hline 33 & Kimia Farma Tbk & KBLF \\
\hline 34 & Lion Metal Works Tbk & LION \\
\hline 35 & Lionmesh Prima Tbk & LMSH \\
\hline 36 & Merck Tbk & MERK \\
\hline 37 & Multi Bintang Indonesia Tbk & MLBI \\
\hline 38 & Mayora Indah Tbk & MYOR \\
\hline 39 & Nippres Tbk & NIPS \\
\hline 40 & Pelangi Indah Canindo Tbk & PICO \\
\hline 41 & Pyridam Farma Tbk & PYFA \\
\hline 42 & Ricky Putra Globalindo Tbk & RICY \\
\hline 43 & Nippon Indosari Corporindo Tbk & ROTI \\
\hline 44 & Supreme Cable Manufacturing and Commerce Tbk & SCCO \\
\hline 45 & Industri Jamu dan Farmasi Sido Muncul Tbk & SIDO \\
\hline 46 & Sekar Bumi Tbk & SKBM \\
\hline 47 & Sekar Laut Tbk & SKLT \\
\hline 48 & Semen Baturaja Persero Tbk & SMBR \\
\hline 49 & Holcim Indonesia Tbk & SMGR \\
\hline 50 & Selamat Sempurna Tbk & SMSM \\
\hline 51 & Star Petrochem Tbk & STAR \\
\hline 52 & Siantar Top Tbk & STTP \\
\hline 53 & Tunas Alfin Tbk & TALF \\
\hline 54 & Mandom Indonesia Tbk & TCID \\
\hline 55 & Surya Toto Indonesia Tbk & TOTO \\
\hline 56 & Trisula International Tbk & TRIS \\
\hline 57 & Tempo Scan PasificTbk & TSPC \\
\hline 58 & Ultrajaya Milk Industry and Trading Company Tbk & ULTJ \\
\hline 59 & Nusantara Inti Corpora Tbk & UNIT \\
\hline 60 & Unilever Indonesia Tbk & UNVR \\
\hline 61 & Voksel Electric Tbk & VOKS \\
\hline 62 & Wismilak Inti Makmur Tbk & WIIM \\
\hline 63 & Wijaya Karya Beton Tbk & WTON \\
\hline & & \\
\hline
\end{tabular}

\section{Analisis Statistik Deskriptif}

Sumber: Data sekunder yang diolah

Di penelitian yang dilakukan ini, data yang ingin diketahui gambarannya yaitu tax avoidance/penghindaran pajak, proporsi dewan komisaris, profitabilitas, dan leverage pada perusahaan industri manufaktur yang terdaftar di BEI (2015-2017). Hasil dari analisis statistik deskriptif dengan menggunakan program Eviews 8.0 sebagai berikut :

Tabel 2: Statistik deskriptif

\begin{tabular}{lccccc}
\hline & TAV & PDK & SZE & ROA & DER \\
\hline Mean & 21.34345 & 0.405883 & 14.69210 & 8.441641 & 0.831270 \\
Maximum & 92.19224 & 0.800000 & 19.50467 & 52.67036 & 4.550000 \\
Minimum & 0.096794 & 0.200000 & 11.80397 & 0.018031 & 0.080000 \\
Std. Dev. & 15.85844 & 0.103411 & 1.563959 & 7.851662 & 0.721359 \\
\hline
\end{tabular}

Sumber: Data diolah dengan Eviews 8.0 
Dilihat pada hasil pengujian statistik deskriptif dari Tabel 2, variabel dependen TAV (tax avoidance) menunjukkan nilai mean (rata-rata) sebesar 21,34345 dengan nilai minimum/terendah 0,096794, maksimumnya sebesar 92,19224 dan nilai deviasi standar sebesar 15,85844. Variabel independen proporsi dewan komisaris (PDK) memiliki nilai mean (rata-rata) sebesar 0,405883 dengan nilai minimum 0,200000, dan nilai maksimum sebesar 0,800000, dengan nilai deviasi standar sebesar 0,103411.Variabel independen ukuran perusahaan (SZE) memiliki nilai mean (rata-rata) 14,69210 dengan nilai minimum/terendah 11,80397, dan nilai maksimum/tertinggi senilai 4,550000, dengan nilai deviasi standar sebesar 1,563959. Variabel independen/bebas ROA menghasilkan nilai mean (rata-rata) sebesar 8,441641 dengan nilai minimum/terendah sebesar 0,018031, dan juga nilai maksimum/tertinggi sebesar 52,67036, dengan nilai deviasi standar senilai 7,851662. Variabel independen/bebas leverage (DER) memiliki nilai mean (rata-rata) 0,831270 dengan nilai minimum 0,080000 , dan nilai maksimum/tertinggi senilai 52,67036, dengan hasil nilai deviasi standar sebesar 0,721359 .

\section{Analisis Pemilihan Model untuk Penelitian Data Panel}

Dari penelitian yang telah dilakukan ini cara yang digunakan untuk memilih model estimasi yang digunakan yaitu dengan memakai ada tiga cara, yakni common effect model, fixed effect model, dan random effect model. Saat menentukan metode yang akan digunakan dan yang sangat cocok berdasarkan penelitian yang dilakukan ini yaitu dengan memakai uji Chow serta uji Haussman. Dari pengujian, fixed effect model yang tepat untuk penelitian ini. Selain itu, uji asumsi klasik untuk data panel juga telah dilaksanakan.

Hasil dari pengujian hipotesis ditunjukkan di Tabel 3 di bawah:

Tabel 3 Hasil Uji Data Panel Fixed Effect Model

\begin{tabular}{ccc}
\hline Variabel & Coefficient & Prob. \\
\hline PDK & -5.190999 & 0.7616 \\
SZE & -29.82525 & 0.0005 \\
ROA & -0.099131 & 0.8153 \\
DER & 22.51632 & 0.0019 \\
C & 443.7654 & 0.0005 \\
\hline
\end{tabular}

Sumber: Data diolahnmenggunakannEviews_8.0

Pada Tabel 3 tersebut bisa dibuat persamaan regresi di bawah ini:

$\mathrm{Y}_{i, t}=443,7654-5,190999 \mathrm{X}_{1 i, t}-29,82525 \mathrm{X}_{2 i, t}-0,099131 \mathrm{X}_{3 i, t}+22,51632 \mathrm{X}_{4 i, t}+e_{i, t}$

Dari uji statistik $\mathrm{T}$ (Uji Signifikansi Parsial) di Tabel 2 di atas bisa dijelaskan pengaruhnya secara parsial setiap variabel independen pada variabel dependen/terikat, yaitu variable SZE (ukuran), dan DER berpengaruh terhadap TAV. Sedangkan variable lain PDK, dan ROA tidak berpengaruh.

\section{Pembahasan}

\section{Pengaruh Proporsi Dewan Komisaris terhadap Tax Avoidance}

Hasil dari pengujian tersebut sesuai dengan hipotesis yang diajukan dan disimpulkan bahwa seberapa banyak proporsi dewan komisaris independen tidak akan mempengaruhi tax avoidance. 
Dari hasil penelitian ini maka dapat diketahui penelitian ini tidak sesuai dengan hipotesis yang telah diajukan serta sesuai pula dengan penelitian sebelumnya yang dilakukan oleh Annisa dan Kurniasih (2016), Maharani dan Suardana (2014), Dewi dan Jati (2014), dan juga Tandean dan Winnie (2016) yang dalam penelitiannya menghasilkan bahwa tax avoidance tidak dipengaruhi oleh adanya proporsi dewan komisaris independen. Sesuai agency theory yakni terdapat pemisahan kewenangan antara pengelola dan pemilik. Hal inipun mungkin dikarenakan dewan komisaris independen hanya melakukan pengawasan pengelolaan pada perusahaan agar berjalan dengan benar, sesuai serta tidak melakukan pelanggaran pada peraturam yang telah berlaku, di sisi lain kewenangan pada penanganan masalah penghindaran pajak lebih dipengaruhi oleh tindakan yang dilakukan pihak manajemen perusahaan yang lebih mengerti masalah pajak didalam perusahaannya.

\section{Pengaruh Ukuran Perusahaan (Size) terhadap Tax Avoidance}

Setelah dilakukan pengujian regresi pada data panel dengan fixed effect model dengan ukuran perusahaan sebagai variabel independen, diperoleh hasil bahwa ukuran perusahaan mempengaruhi tax avoidance. Hal ini merupakan penelitian yang sesuai dengan hipotesis yang diajukan dan dapat disimpulkan bahwa ukuran perusahaan yang semakin besar dapat menimbulkan effective tax rate (ETR) pada perusahaan akan makin rendah dengan kata lain tingkat tax avoidance di perusahaan akan semakin menjadi besar pula. Hal tersebut sesuai dengan hipotesis yang diajukan.

Hasil menunjukkan bahwa ukuran perusahaan mempengaruhi penghindaran pajak (sejalan dengan Swingly dan Sukartha (2015), Darmawan dan Sukartha (2014), Diantari dan Ulupui (2016), serta Dharma dan Ardiana (2016)), semakin besar ukuran suatu perusahaan maka makin besar pula sumber daya yang dimiliki oleh suatu perusahaan tersebut untuk mengelola beban pajaknya. Sesuai dengan agency theory, dimana sumber daya yang telah dimiliki oleh perusahaan dapat digunakan oleh para agen untuk memaksimalkan kompensasi kinerja agen itu sendiri, yakni melalui usaha penekanan pada beban pajak pada perusahaan untuk memaksimalkan kinerja perusahaan.

\section{Pengaruh Profitabilitas (ROA) terhadap Tax Avoidance}

Pada pengujian pada hipotesis ketiga dengan pengujian regresi pada data panel fixed effect model dengan ROA sebagai variabel independen/bebas, memperoleh hasil yang menunjukkan bahwa ROA tidak mempengaruhi tax avoidance. Sehingga meskipun nilai profitabilitas pada level ROA tinggi, namun, hal itu tidak mempengaruhi tax avoidance dalam perusahaan.

Diperoleh hasil tidak sesuai dengan hipotesis yang diajukan serta juga tidak sejalan dengan Darmawan dan Sukartha (2014), Dewi dan Wirajaya (2013), Dewinta dan Setiawan (2015) serta Arianandini dan Ramantha (2018) dimana hasil penelitian sebelumnya mennyebutkan ROA dapat berpengaruh, baik secara positif maupun negatif terhadap tax avoidance. Juga tidak sejalan dengan teori keagenan dimana ketika laba yang besar diperoleh perusahaan meningkat, menimbulkan penghindaran pajak pada perusahaan akan cenderung dilakukan.

\section{Pengaruh Leverage terhadap Tax Avoidance}

Pengujian hipotesis keempat dengan pengujian regresi pada data panel dengan fixed effect model dengan leverage sebagai variabel independen, diperoleh hasil leverage mempengaruhi tax avoidance. Sehingga perubahan nilai pada leverage perusahaan dapat mempengaruhi tax avoidance pada perusahaan.

Hasil penelitian yang dilakukan ini sejalan dengan Dewinta dan Setiawan (2015) dimana hasil penelitian sebelumnya menyebutkan leverage dapat mempengaruhi secara positif 
terhadap tax avoidance. Juga tidak sesuai dengan teori keagenan dimana ketika laba yang besar diperoleh perusahaan meningkat perusahaan akan lebih cenderung untuk melakukan praktik penghindaran pajak.

\section{KESIMPULAN DAN SARAN}

Tax avoidance tidak mendapat mempengaruhi profitabilitas, dan dewan komisaris independen. Namun, pengaruhnya signifikan pada ukuran perusahaan (size) dan Leverage. Keterbatasan pada penelitian ini adalah: Perusahaan dalam industri manufaktur yang terdapat di Bursa Efek Indonesia dalam periode 2015-2017 adalah sampel yang digunakan dalam penelitian ini dan dalam rentang tiga tahun tersebut hanya 63 perusahaan yang memenuhi persyaratan penelitian ini. Proporsi dewan komisaris independen, ukuran perusahaan, ROA, serta leverage merupakan variabel independen pada penelitian ini.

Sebaigai implikasi dari penelitian ini, perlu adanya kesadaran dan pemahaman dari semua perusahaan terkait pentingnya membayar pajak tanpa adanya pemanfaatan dari adanya tax avoidance yang mana hal tersebut legal/sah. Pemanfaatan dari adanya tax avoidance yang dilakukan oleh perusahaan membuat penerimaan negara atas pajak menjadi berkurang dan dengan kesadaran mengenai hal ini akan membantu negara serta membantu masyarakat serta pemerintah karena penerimaan negara dari pembayaran pajak tersebut adalah digunakan sebesar-besarnya demi kemakmuran masyarakat. Dan juga perlu dari sisi fiskus pajak, perlu dilakukan pengawasan yang lebih terhadap perusahaan, agar tax avoidance tidak mudah dilakukan.

Dengan adanya keterbatasan penelitian tersebut, maka disarankan untuk menggunakan sampel lebih dari tiga periode menambah periode. Selain itu, perlunya menambahkan variabel penting lain baik dari proksi corporate governance maupun variabel keuangan lainnya yang dapat mempengaruhi tax avoidance.

\section{DAFTAR PUSTAKA}

Annisa, N. A., dan Kurniasih, L. (2012). Pengaruh corporate governance terhadap tax avoidance. Jurnal Akuntansi dan Auditing, 8(2), 95-189.

Annuar, H. A., Salihu, I. A., dan Obid, S. N. (2014). Corporate ownership, governance and tax avoidance: An interactive effects. Procedia - Social and Behavioral Sciences, 164(2014), $150-160$.

Arianandini, P. W., dan Ramantha, I. (2018). Pengaruh profitabilitas, leverage, dan kepemilikan institusional pada tax avoidance. E-Jurnal Akuntansi Universitas Udayana, 22(3), 2088-2116.

Armstrong, C., Blouin, J., dan Jagolinzer, A. (2015). Corporate governance, incentives, and tax avoidance. Journal of Accounting and Economics, 60(1), 1-17.

BAPEPAM-LK. (2012). Keputusan ketua badan pengawas pasar modal dan lembaga keuangan nomor: KEP-643/BL/2012. Jakarta: https://www.ojk.go.id. Retrieved from https://www.ojk.go.id/Files/regulasi/pasar-modal/bapepam-pm/emiten-pp/peraturanlain/6.IX.I.5.pdf

Basuki, A. T., dan Prawoto, N. (2016). Analsis regresi dalam penelitian ekonomi dan bisnis (Dilengkapi aplikasi SPSS dan EVIEWS). Depok: PT. Rajagrafindo Persada.

Chen, S., Chen, X., Cheng, Q., dan Shevlin, T. (2010). Are family firms more tax aggressive than nonfamily firms? Journal of Financial Economics, 91(1), 41-61.

Damayanti, F., dan Susanto, T. (2015). Pengaruh komite audit, kualitas audit, kepemilikan institusional, risiko perusahaan dan Return On Asset terhadap tax avoidance. Jurnal Bisnis dan Manajemen, 5(2), 187-206. 
Dananjaya, D. G., dan Ardiana, P. A. (2016). Proporsi dewan komisaris independen sebagai pemoderasi pengaruh kepemilikan institusional pada manajemen laba. E-Jurnal Akuntansi Universitas Udayana,15(2), 1595-1622.

Darmawan, I. H., dan Sukartha, I. (2014). Pengaruh penerapan corporate governance, leverage, Return On Assets, dan ukuran perusahaan pada penghindaran pajak. EJurnal Akuntansi Universitas Udayana. 9(1), 143-161.

Desai, M., dan Dharmapala, D. (2005). Corporate tax avoidance and firm values. NBER Working Paper No. 11241.

Dewi, A. M., dan Wirajaya, A. (2013). Pengaruh struktur modal, profitabilitas, dan ukuran perusahaan pada nilai perusahaan. E-Jurnal Akuntansi Universitas Udayana, 4(2), 358-372.

Dewi, N. K., dan Jati, I. (2014). Pengaruh karakter eksekutif, karakteristik perusahaan, dan dimensi tata kelola perusahaan yang baik pada tax avoidance di Bursa Efek Indonesia. E-Jurnal Akuntansi Universitas Udayana, 6(2), 249-260.

Dewinta, I. R., dan Setiawan, P. E. (2016). Pengaruh ukuran perusahaan, umur perusahaan, profitabilitas, leverage, dan pertumbuhan penjualan terhadap tax avoidance. E-Jurnal Akuntansi Universitas Udayana, 14(3), 1584-1613.

Dharma, I. M., dan Ardiana, P. A. (2016). Pengaruh leverage, intensitas aset tetap, ukuran perusahaan, dan koneksi politik terhadap tax avoidance. E-Jurnal Akuntansi Universitas Udayana, 15(1), 584-613.

Diantari, P. R., dan Ulupui, I. A. (2016). Pengaruh komite audit, proporsi komisaris independen, proporsi komisaris independen, dan proporsi kepemilikan institusional terhadap tax avoidance. E-Jurnal Akuntansi Universitas Udayana, 16(1), 702-732.

Eksandy, A. (2017). Pengaruh Komisaris independen, komite audit, dan kualitas audit terhadap penghindaran pajak (Tax Avoidance). Competitive, 1(1), 1-20.

Fama, E. F., dan French, K. R. (1992). The cross-section of expected stock returns. The Journal of Finance, 47(2), 427-465.

Friese, A., Link, S., dan Mayer, S. (2006). Taxation and corporate governance. Working Paper.

Ghozali, I. (2011). Aplikasi analisis multivariate dengan program SPSS. Semarang: Badan Penerbit Universitas Diponegoro.

Ghozali, I. (2012). Aplikasi analisis multivariate dengan program SPSS. Semarang : Badan Penerbit Universitas Diponegoro.

Gujarati, Damodar. (2006). Dasar-dasar ekonometri. Jakarta: Erlangga.

Hidayat, A. (2019, 4 14). statistikian. Retrieved from Penjelasan Metode Analisis Regresi Data Panel: https://www.statistikian.com/2014/11/regresi-data-panel.html (akses 6 April 2019)

Hutagaol, J. (2007). Perpajakan : Isu-isu kontemporer. Yogyakarta: Graha Ilmu.

Jensen, M. C., dan Meckling, W. H. (1976). Theory of the firm: Managerial Behavior, agency costs and ownership structure. Journal of Financial Economics, 3(4), 305-360.

Kep-339/BEJ/07-2001. (2001). Pencabutan ketentuan huruf C.2.e peraturan pencatatan efek nomor I-A. Jakarta: PT. Bursa Efek Indonesia.

Kurniasih, T., dan Sari, M. M. (2013). Pengaruh Return On Assets, leverage, corporate governance, ukuran perusahaan, dan kompensasi rugi fiskal terhadap tax avoidance. E-Jurnal Akuntansi Universitas Udayana, 18(1), 1410-4628.

Maharani, I. A., dan Suardana, K. A. (2014). Pengaruh Corporate governance, profitabilitas, dan karakter eksekutif pada tax avoidance perusahaan manufaktur. E-jurnal Akuntansi Universitas Udayana, 9(2), 525-539.

Pohan, H. (2009). Analisis pengaruh kepemilikan institusi, rasio Tobin Q, akrual pilihan, tarif efektif pajak, dan biaya pajak ditunda terhadap penghindaran pajak pada perusahaan 
publik. Jurnal Informasi, Perpajakan, Akuntansi dan Keuangan Publik, 4(2),113 135.

Putra, A. S., dan Nuzula, N. F. (2017). Pengaruh corporate governance terhadap profitabilitas (Studi pada perusahaan perbankan yang terdaftar di bursa efek indonesia periode 2013-2015). Jurnal Administrasi Bisnis (JAB), 47(1), 103-112.

Sugiyono. (2013). Metode penelitian bisnis (Pendekatan kuantitatif, kualitatif, $R$ dan D). Bandung: Alfabeta.

Swingly, C., dan Sukartha, I. (2015). Pengaruh karakter eksekutif, komite audit, ukuran perusahaan, leverage dan sales growth pada tax avoidance. E-Jurnal Akuntansi Universitas Udayana 10(1), 47-62.

Tandean, V. A., dan Winnie. (2016). The effect of good corporate governance on tax avoidance: An empirical study on manufacturing companies listed in IDX period 2010-2013. Asian Journal Accounting Research, 1(1), 28 - 38.

Ujiyantho, M. A., dan Pramuka, B. A. (2007). Mekanisme corporate governance, manajemen laba, dan laporan keuangan. Simposium Nasional Akuntansi X, .

Undang-Undang Republik Indonesia Nomor 16 tahun, 2. (2009). Penetapan peraturan pemerintah pengganti undang-undang nomor 5 tahun 2008 tentang perubahan keempat atas undang-undang nomor 6 tahun 1983 tentang ketentuan umum dan tata cara perpajakan menjadi undang-undang-undang. Jakarta: Menteri Hukum dan Hak Asasi Manusia Republik Indonesia.

Yuliani, V., dan Suyanto. (2019). Pengaruh penerapan corporate governance, Return On asset, dan leverage terhadap aggresive tax avoidance pada perusahaan manufaktur yang terdaftar di Bursa Efek Indonesia. Jurnal Akuntansi Pajak Dewantara, 1(1), 114. 